\title{
PENDUDUK MUSLIM SEBAGAI \\ POTENSI PASAR PERBANKAN SYARIAH \\ (Studi Komparasi Kekuatan Pasar Perbankan di Indonesia)
}

\author{
Ely Masykuroh
}

\begin{abstract}
Abstrak:
Perkembangan perbankan syariah telah mengalami progres yang sangat berarti bukan hanya di negara-negara Islam saja, namun di negara-negara barat seperti Eropa, Australia dan Amerika, tak terkecuali Indonesia. Meskipun perkembangan perbankan syariah menggembirakan dan penelitian terkait perbankan syariah juga meningkat, namun hanya sedikit literatur akademik dan juga penelitian yang mencoba menjelaskan tentang implikasi ekonomi dari keberadan bank syariah yang dikatakan berbeda dengan bank konvensional. Jumlah populasi penduduk muslim yang besar di Indonesia seharusnya menjadi potensi kekuatan pasar bagi perbankan syariah, sehingga diasumsikan permintaan terhadap jasa perbankan syariah lebih tinggi dibanding pada bank konvensional ditambah lagi dengan adanya pelarangan riba dalam Islam, seharusnya berdampak pada pengambilan keputusan bertransaksi dengan pihak perbankan. Berdasarkan latar belakang yang sudah dijelaskan, maka penelitian ini mencoba mengukur dan membandingkan kekuatan pasar perbankan syariah dan konvensional di Indonesia dengan menggunakan sampel penelitian meliputi 9 bank dimasing masing kelompok sejak tahun 2011-2015 dengan menggunakan Lerner Index untuk mengukur kekuatan pasarnya. Hasil penelitian menunjukkan tidak adanya perbedaan yang signifikan terhadap kekuatan pasar pada kedua bentuk perbankan baik syariah maupun konvensional meskipun secara rata rata kekuatan pasar bank konvensional ternyata lebih tinggi.
\end{abstract}

Keywords: Lerner Index, Revenue, Market Power, Price

\section{PENDAHULUAN}

Prinsip utama ekonomi Islam adalah larangan riba (usury). Riba umumnya dipahami sebagai keuntungan yang berlebihan pada 
pinjaman uang, dan larangan tersebut tidaklah unik di Islam. Sehingga dalam praktek perbankan syariah bahwa setiap bunga, bahkan pada titik terendahpun merupakan riba. Bunga tidak hanya harus diatur, tapi dilarang sama sekali. Larangan bunga jelas menciptakan suatu kebutuhan untuk metode perbankan yang tanpa bunga. Dua jenis utama transaksi yang digunakan dalam perbankan Islam adalah laba (marjin keuntungan) dan bagi hasil (Selanjutnya disebut PLS) dan metode mark-up.

Sejak beroperasinya Bank Muamalah Indonesia pada tahun 1992, sampai saat ini terdapat lebih dari 8 Bank Umum dan Unit Syariah di Indonesia. Seperti yang kita ketahui bersama pada tahun 1998 dimana krisis moneter tengah menghantam Indonesia, eksistensi bank syariah masih menunjukkan kinerja yang relatif lebih baik dibanding perbankan konvensional. Hal ini dapat dilihat dari relatif lebih rendahnya penyaluran pembiayaan yang bermasalah (Non Perforance Financing) pada bank syariah dan tidak terjadinya negative spread dalam kegiatan operasionalnya ${ }^{1}$. Kondisi ini tentu saja dapat dipahami mengingat tingkat pengembalian bank syariah tidak mengacu pada tingkat suku bunga namun berdasarkan bagi hasil yang mana besarnya menyesuaian tingkat keuntungan nasabah.

Keberadaan perbankan syariah di Indonesia mendapatkan pijakan hukum yang kuat sejak lahirnya Undang Undang Perbankan Nomor 7 Tahun 1992 dan telah direvisi melalui Undang Undang Nomor 10 Tahun 1998 yang dengan tegas mengakui keberadaan dan berfungsinya Bank Bagi Hasil atau Bank Syariah². Perkembangan yang signifikan di dalam perundang-undangan perbankan syariah di Indonesia terjadi sejak 2008, yakni dengan dikeluarkannya Undang Undang Nomor 21 Tahun 2008 tentang Perbankan Syariah. Dikeluarkannya undang-undang tersebut dilatarbelakangi oleh adanya kebutuhan masyarakat Indonesia akan jasa-jasa perbankan syariah yang semakin meningkat. ${ }^{3} \mathrm{Hal}$ ini mengingat lebih dari $90 \%$ jumlah penduduk Indonesia mayoritas adalah Muslim.

${ }^{1}$ Abdul Ghafur Anshori, Perbankan Syariah di Indonesia, Edisi Revisi (Yogyakarta: Gajah Mada University Press, 2009), 9.

${ }^{2}$ Muhammad, Manajemen Bank Syarah, Edisi Revisi (Yogyakarta: AMP YKPN (UPP), 2005), 15.

${ }^{3}$ Abdul Ghafur Anshori, Perbankan Syariah di Indonesia, 7. 
Melihat perkembangan perbankan syariah yang cukup menggembirakan mendorong banyak peneliti untuk melakukan kajian terkait perkembangan dan kinerjanya. Beberapa penelitian tersebut dapat dilihat di tabel 1.1. Rosly dan Abu Bakar, mencoba membandingkan kinerja bank syariah dan bank konvensional di Malaysia dengan menggunakan analisa rasio ROA (Return On Assets), ROD (Return On Deposit), AU (Assets Utilization), OER (Operating Efficiency Ratio), PM (Profit Margin) dan juga Investasi/Interest Margin. Dari hasil penelitian ditemukan bahwa Bank syariah memiliki tingkat profitabilitas lebih tinggi dibanding bank konvensional namun dinilai kurang effisien ${ }^{4}$. Samad (2004) mencoba melakukan hal yang sama di Bahrain dengan menggunakan rasio Profitabilitas, Liquiditas dan Resiko kredit. Hasil temuan menunjukkan antara kedua jenis bank tidak ditemukan perbedaan yang signifikan dalam profitabilitas dan likuiditas, dan bank syariah sedikit lebih rendah resiko kreditnya dibanding bank konvensional ${ }^{5}$. Senada dengan penelitian sebelumnya, Abdullah et al. (2007), Kader \& Asorpate (2007), Marzuki (2010), Ateeq (2011), Arshad (2011); Siraj \& Pillai (2012); Usman (2012) dengan analisa profitabilitas, likuiditas, solvabilitas, resiko kredit mencoba melakukan penilaian kinerja bank syariah. Sementara Kouser (2012) mencoba melakukan penilaian kinerja bank syariah dengan menggunakan analisis $\mathrm{CAMEL}^{6}$. Hanif, mencoba melakukan penilaian kinerja bank syariah bukan hanya dengan menggunakan analisa kinerja keuangan yang berlaku namun juga mencoba melihat motivasi nasabah yang mendorong nasabah memilih bank syariah. Hanif menemukan hasil yang berbeda terhadap kinerja keuangan bank syariah dan konvensioanl serta motivasi yang nasabah terhadap kedua bank tersebut? ${ }^{?}$.

\footnotetext{
${ }^{4}$ Rosly, Saiful a \& Mohd A Abu Bakar, 2003, Performance of Islamic and mainstream banks in Malaysia, International Journal of Social Economics, Vol 30 (11/12), 1249-1265.

${ }^{5}$ Samad, Abdus and Hasan, M. Kabir, 2000. "The Performance of Malaysian Islamic Bank During 1984-1997: An Exploratory Studi”, International Journal of Islamic Financial Services, Vol.1. (1), 1-14.

${ }^{6}$ Kauser, Rehana \& Irum Saba. 2012. Gauging the financial performance of banking sector using CAMEL model: comparition of conventional bank, mixed and pure Islamic bank in Pakistan. International Research Journal of Finance and Economics. Issues 82 (2012), hal. 67-89.

${ }^{7}$ Hanif, Muhammad, Mahris Tariq Arsshiya Taher Wajesh ul Momeneen. 2012. Comparative performance study of conventional and Islamic banking is Pakistan. International Research Journal of Finance and Economics, Issues 83 (2012) hal. 62-73.
} 


\section{4 | Ely Masykuroh}

Meskipun perkembangan perbankan syariah menggembirakan dan penelitian terkait perbankan syariah juga meningkat, namun hanya sedikit literatur akademik dan juga penelitian yang mencoba menjelaskan tentang implikasi ekonomi dari keberadan bank syariah yang dikatakan berbeda dengan bank konvensional. Apakah permintaan pasar terhadap jasa layanan perbankan syariah lebih besar dan mampu mendorong pertumbuhan ekonomi dibanding perbankan konvensional.

Kata kunci di sini adalah kekuatan pasar bank syariah. Kekuatan pasar adalah kemampuan perusahaan untuk mempengaruhi harga produk dan karena itu langsung terkait dengan persaingan karena persaingan yang lebih besar mengurangi kekuatan pasar. Bank Islam mungkin memiliki keuntungan dan peluang yang lebih besar. Misalnya, dari nasabah muslim dengan permintaan yang lebih elastis didorong oleh prinsip-prinsip agama yang meningkatkan kekuatan pasar yang lebih besar dari bank konvensional.

Di sebagian besar negara dengan bank syariah, bank-bank syariah beberapa hidup berdampingan dengan bank konvensional. Oleh karena itu, masyarakat dengan tingkat keyakinan atau agama akan berusaha untk menjalankan syariat dan dimungkinkan lebih setia kepada bank syariah dibandingkan masyarkat atau nasabah nonrelegious di semua kategori bank. El-Gamal (2007) menyebutkan bahwa beberapa penyedia dan pengamat industri bank syariah mengacu pada ini biaya tambahan dan harga untuk klien bank syariah sebagai 'biaya menjadi Muslim, dan menekankan kemungkinan over pricing tersebut ${ }^{8}$. Kuran (2004) mendukung pandangan ini dengan mengamatibahwabanksyariahyangberoperasidiTurkiberhasildengan cepat menarik satu persen dari total simpanan hanya dalam beberapa bulan dengan sejumlah kecil cabang 9 . Perbandingan kekuatan pasar bank syariah dan konvensional adalah masalah mendasar, karena beberapa penelitian telah menunjukkan pentingnya kekuatan pasar untuk pengembangan Islam (Petersen dan Rajan, 1995'10: Jayaratne

${ }^{8}$ El-Gamal, M. 2007. Incoherence of Contract Based Islamic Financial Jurisprudence in The Age of Financial Engineering, Rice Univercity, mimeo.

${ }^{9}$ Kuran, T. 1995. Islam and Mammon. Princeton Univercity Press: Princeton.

${ }^{10} \mathrm{~W}$ Petersen and Rajan R, 1995. The effect of credit market competetionon on landing relationships. Quarterly Journal of Economics. 110: 407-443. 
dan Strahan, $1996^{11}$; Cetorelli dan Gambera, 2001) ${ }^{12}$. Singkatnya, argumen di sini adalah bahwa persaingan bank yang lebih besar meningkatkan akses kredit dengan biaya lebih rendah. Yang, pada gilirannya, menyebabkan peningkatan pinjaman oleh perusahaan dan meningkatkan pertumbuhan. Peningkatan persaingan bank yang dapat mendukung pengembangan keuangan dengan meningkatkan akses ke produk keuangan dan, sebagai literatur menunjukkan, adanya hubungan positif antara pengembangan keuangan dan pembangunan ekonomi yang mendorong pembangunan ekonomi. ${ }^{13}$ Berdasarkan paparan di atas, maka penelitian ini mencoba mengkaji apakah terdapat perbedaan kekuatan pasar pada perbankan syariah dan konvensional di Indonesia.

Kekuatan pasar adalah kemampuan perusahaan untuk mempengaruhi harga produk dan karena itu langsung terkait dengan persaingan karena persaingan yang lebih besar mengurangi kekuatan pasar. Bank Islam mungkin manfaat, misalnya, dari klien dengan permintaan yang lebih elastis didorong dengan prinsip-prinsip agama yang menganugerahkan kekuatan pasar yang lebih besar dari bank konvensional. Di sebagian negara dengan bank syariah, bank-bank syariah beberapa hidup berdampingan dengan bank konvensional. Oleh karena itu, klien agama untuk menghormati syariat mungkin lebih setia kepada bank syariah dibandingkan klien non-religius di semua kategoribank. Memang, El-Gamal (2007) menyebutkan bahwa beberapa penyedia dan pengamat industri bank syariah mengacu pada ini biaya tambahan dan harga untuk klien bank syariah sebagai "biaya menjadi Muslim", dan menekankan kemungkinan overpricing tersebut. Kuran (2004) mendukung pandangan ini dengan mengamati bahwa bank syariah yang beroperasi di Turki berhasil dengan cepat menarik satu persen dari total simpanan hanya dalam beberapa bulan dengan sejumlah kecil cabang. Perbandingan kekuatan pasar bank syariah dan konvensional adalah masalah mendasar, karena beberapa penelitian telah menunjukkan pentingnya kekuatan pasar

${ }^{11}$ J. Jayaratne and P Strahan. 1996. The finance-growth nexus: Evidence from bank branch deregulation. Quarterly Journal of Economics. 111: 639-670.

${ }^{12}$ Cetorelli $\mathrm{N}$ and M Gambera. 2001. Banking market structure, financial dependence and growth; International Evidence from Industry data. Journal of Finance 56:617-648.

${ }^{13}$ Levina R. 2005. Finace and growth dalam Aghion and Durlauf. Handbook of Economic Growth, Elselvier: North-Holland. 
untuk pengembangan Islam (Petersen dan Rajan, 1995; Jayaratne dan Strahan, 1996; Cetorelli dan Gambera, 2001). Singkatnya, argumen di sini adalah bahwa persaingan bank yang lebih besar meningkatkan akses kredit dengan biaya lebih rendah. Yang pada gilirannya, menyebabkan kemungkinan pinjaman oleh perusahaan dan meningkatkan pertumbuhan. Moe umum, peningkatan persaingan bank yang dapat mendukung pengembangan keuangan dengan meningkatkan akses ke produk keuangan dan, sebagai literatur menunjukkan, menciptakan hubungan positif antara pengembangan keuangan dan pengembangan ekonomi (Levina, 2005) yang mendorong pembangunan ekonomi.

Para ekonom mendefinisikan market power sebagai kemampuan perusahaan atau sekelompok perusahaan mempengaruhi pasar untuk mendapatkan keuntungan dengan cara menetapkan harga pada tingkat yang kompetitif dalam jangka waktu yang panjang. Berdasarkan definisi tersebut dapat disimpulkan bahwa perusahaan yang memiliki kekuatan pasar adalah perusahaan yang tetap mendapatkan keuntungan pada saat terjadi kenaikan harga pada tingkat berapapun, karena setiap perusahaan dapat menaikkan harga, namun tidak semua perusahaan mendapatkan keuntungan karena peningkatan harga tersebut. ${ }^{14}$

Beberapa perusahaan memiliki perbedaan kemampuan dalam menentukan tingkat harga dikarenakan perbedaan jumlah biaya-biaya yang dikeluarkan dan tingkat keuntungan yang ingin dicapai. Oleh karena itu kekuatan pasar merupakan kemampuan perusahaan dalam menentukan tingkat harga yang berbeda dari para kompetitornya tanpa harus merasa ketakutan akan perpindahan konsumen ke produk substitusi atau produk kompetitor. Kekuatan pasar dapat menjadi potensi bagi perusahaan untuk meraup keuntungan yang sebesar-besarnya. Karena perusahaan yang memiliki kekuatan pasar dapat menentukan harga sebesar-besarnya tanpa harus takut kehilangan konsumen.

Menurut Maudos \& Guevara, analisis tentang kekuatan pasar dalam konteks industri perbankan menjadi sangat penting karena dapat menyebabkan tingginya biaya intermediasi keuangan dan

${ }^{14}$ American Bar Association (ABA), Market Power Handbook: Competition Law and Economic Foundations (USA: ABA Publishing, 2005), hal. 1-2. 
rendahnya jumlah simpanan dan investasi, sehingga berdampak pada rendahnya pertumbuhan ekonomi. Di sisi lain, kekuatan pasar juga dapat berpengaruh positif tingginya profitabilitas perbankan yang berguna untuk menghadapi bermacam-macam risiko dan menyebabkan stabilitas sistem perbankan. ${ }^{15}$

Teori market power menyatakan bahwa hanya perusahaan yang memiliki market share dan differensiasi produk yang memiliki kekuatan pasar dalam menentukan harga dan menghasilkan keuntungan yang besar. ${ }^{16}$ Bank Islam di Indonesia mungkin memiliki market share yang sangat besar, yaitu mayoritas penduduk di Indonesia adalah muslim dengan permintaan yang lebih elastis didorong dengan prinsip-prinsip agama yang menganugerahkan kekuatan pasar yang lebih besar dari bank konvensional. Oleh karena itu, klien agama untuk menghormati syariat mungkin lebih setia kepada bank syariah dibandingkan klien non-religius di semua kategori bank. Selain itu, differensiasi produk Bank Islam juga memiliki fitur yang unik dibandingkan dengan bank konvensional yaitu produk-produk yang ditawarkan oleh Bank Islam berbasiskan bagi hasil sebagai alternatif dari sistem bunga yang diterapkan oleh Bank Konvensional.

Berdasarkan teori, bahwa kemampuan perusahaan untuk mempengaruhi harga produk tertentu terkait dengan perilaku konsumen. Sedangkan perilaku konsumenitu sendiri dipengaruhioleh banyak faktor diantaranya adalah kepatuhan pada prinsip agama yang dianut. Sehingga perbankan syariah sebagai salah satu lembaga jasa keuangan dan termasuk unit trust tentu saja sangat dipengaruhi oleh kekuatan permintaan/pasar. Di Indonesia mayoritas penduduknya adalah muslim dan dianggap sebagai kekuatan dan peluang bagi perbankan syariah untuk memenangkan dan memenuhi permintaan pasar jika dibandingkan dengan perbankan konvensional. Sehingga hipotesis yang dikembangkan dalam penelitian ini adalah kekuatan pasar (market power) perbankan syariah lebih besar dibandingkan kekuatan pasar perbankan konvensional di Indonesia.

${ }^{15}$ Joaquin Maudos and Juan Fernandez de Guevara, The Cost of Market Power in Banking: Social Welfare Loss VS Ineffeciency Cost, MPRA Paper, No. 15253, http://mpra. ub.uni-muenchen.de/15253/, hal. 1-36.

${ }^{16} \mathrm{~W}$ illiam G. Sepherd, The Element of Market Structure, The Review of Economics and Statistics, Vol. 54, No. 1 (Feb, 1972), pp. 25-37. 
Populasi dalam penelitian ini adalah seluruh Bank Umum Syariah dan Bank Umum Konvensional di Indonesia yang mempublikasikan laporan keuangannya. Menurut catatan Bank Indonesia (BI) sampai dengan tahun 2012 terdapat 11 Bank Umum Syariah baik Devisa maupun non-Devisa dan seluruh bank umum konvensional di Indonesia. Sementara jumlah populasi bank umum konvensional yang devisa sebanyak 36 bank dan non devisa 30 bank (Statistik BI: 2002). Penelitian ini bermaksud membuat generalisasi dengan kesalahan yang relatif kecil, maka tekhnik sampling dalam penelitian ini menggunakan purposive sampling yaitu tekhnik penentuan sampel dengan pertimbangan/kriteria tertentu. ${ }^{17}$ Sampel dalam penelitian ini adalah Bank Umum Syariah dan Bank Umum Konvensional yang terdaftar di Bank Indonesia/Otoritas Jasa Keuangan dari tahun 2011-2015 dengan kriteria bahwa Bank Umum Syariah dan Bank Umum Konvensional tersebut telah menerbitkan laporan keuangan tahunan yang sudah diaudit oleh auditor independen untuk periode yang berakhir tanggal 31 Desember selama tahun 2011-2016. Sedangkan untuk pengambilan sampel Bank Umum Konvensional dilakukan dengan menggunakan desain non-probaility sampling dimana elemen dari populasi tidak mempunyai kesempatan yang sama untuk dipilih sebagai subyek sampel penelitian, sehingga jumlah sampel Bank Umum Konvensional ditentukan jumlahnya sama besarnya dengan sampel Bank Umum Syariah karena penelitian ini menggunakan analisis perbandingan dengan tekhnik uji beda ratarata. Maka kriteria penentuan sampel dalam penelitian ini adalah sebagai berikut:

Tabel 1. Kriteria Sampel Penelitian

\begin{tabular}{lcc}
\hline \multicolumn{1}{c}{ Pertimbangan Kriteria Penentuan Sampel } & BUS & BUK \\
\hline $\begin{array}{l}\text { Jumlah Bank Umum yang terdaftar di Bank Indonesia/ } \\
\text { Otoritas Jasa Keuangan periode 2011-2015 }\end{array}$ & 12 & 56 \\
\hline $\begin{array}{l}\text { (-) Tidak menyajikan laporan keuangan tahunan yang } \\
\text { sudah diaudit oleh auditor independen untuk periode } \\
\text { yang berakhir 31 Desember selama tahun 2011-2015 }\end{array}$ & 3 & 0 \\
\hline Jumlah Bank Umum yang menjadi sampel & 9 & 9 \\
\hline
\end{tabular}

${ }^{17}$ Sugiyono, Metode Penelitian Bisnis (Pendekatan Kuantitatif, Kualitatif dan RED) (Bandung: Alfabeta, 2008), hal. 116 dan 122. 
Tabel 2. Perbankan Sampel Penelitian

\begin{tabular}{lll}
\hline TAHUN & \multicolumn{1}{c}{ BANK SYARIAH } & \multicolumn{1}{c}{ BANK KONVENSIONAL } \\
\hline \multirow{2}{*}{2011} & BSM, BMI, MEGA, BNI, BRI, & BRI, BNI, BTN, MANDIRI, \\
& BII, BUKOPIN, PANIN, BCA & $\begin{array}{l}\text { BCA, DANAMON, BUKOPIN, } \\
\text { MEGA, PANIN }\end{array}$ \\
\hline \multirow{2}{*}{2012} & BSM, BMI, MEGA, BNI, BRI, & BRI, BNI, BTN, MANDIRI, \\
& BII, BUKOPIN, PANIN, BCA & BCA, DANAMON, BUKOPIN, \\
& MEGA, PANIN \\
\hline \multirow{2}{*}{2013} & BSM, BMI, MEGA, BNI, BRI, & BRI, BNI, BTN, MANDIRI, \\
& BII, BUKOPIN, PANIN, BCA & BCA, DANAMON, BUKOPIN, \\
& MEGA, PANIN \\
\hline \multirow{2}{*}{2014} & BSM, BMI, MEGA, BNI, BRI, & BRI, BNI, BTN, MANDIRI, \\
& BII, BUKOPIN, PANIN, BCA & BCA, DANAMON, BUKOPIN, \\
& & MEGA, PANIN \\
\hline \multirow{2}{*}{2015} & BSM, BMI, MEGA, BNI, BRI, & BRI, BNI, BTN, MANDIRI, \\
& BII, BUKOPIN, PANIN, BCA & BCA, DANAMON, BUKOPIN, \\
& & MEGA, PANIN \\
\hline
\end{tabular}

Data yang digunakan dalam penelitian ini diambil dari laporan keuangan tahunan periode 2011-2015 yang telah dipublikasikan dan diaudit oleh auditor independen. Dikarenakan data yang diambil berasal dari dokumentasi maka data penelitian ini bersifat data sekunder. ${ }^{18}$ Dalam penelitian ini, kekuatan pasar diukur dengan menggunakan Indeks Lerner, dimana kekuatan pasar merupakan selisih antara harga dengan marginal cost dibagi dengan harga jasa itu sendiri. Sedangkan harga (price) merupakan rasio dari total pendapatan (Total Revenue/TR) dengan total aset. Sedangkan Marginal Cost (MC) merupakan rasio dari Total Cost (TC) dibandingkan dengan Total Aset. Sementara TC merupakan nilai kumulatif dari Biaya Tenaga Kerja, Biaya Non Interest dan Biaya Bunga/Bahas. Sehingga formulasi dari Indeks Lerner (Lerner Index) adalah sebagai berikut:

$$
L I=\frac{\text { Price }-\mathrm{MC}}{\text { Price }}
$$

${ }^{18}$ Sekaran, U \& Roger Bougie, 2010. Research Methods for Business A Skill Building Approach, Fifth Edition United Kingdom: John Wiley \& Sons Ltd, pp. 276-278. 


$$
\begin{gathered}
\text { Price }=\frac{T R}{\text { Total Aset }} \\
\mathrm{MC}=\frac{\mathrm{TC}}{\text { Total Aset }}
\end{gathered}
$$

$\mathrm{TC}=$ Biaya TK, Biaya Non Interest dan Biaya Bahas

Teknik analisis data yang digunakan pada penelitian ini menggunakan Uji beda Independent sample T-test digunakan untuk menguji dua rata-rata dari dua kelompok data yang independent, yaitu rata-rata indeks Lerner Perbankan Syariah dan Perbankan Konvensional. Data yang digunakan biasanya berskala interval atau rasio.

$$
t=\frac{\bar{X}_{1}-\bar{X}_{2}}{\sqrt{\frac{\left(n_{1}-1\right) S_{1}^{2}+\left(n_{2}-1\right) S_{2}^{2}}{n_{1}+n_{2}-2}\left(\frac{1}{n_{1}}+\frac{1}{n_{2}}\right)}}
$$

Keterangan:

$\begin{array}{ll}\mathrm{t} & \text { : nilai t hitung } \\ \mathrm{X}_{1} & \text { : rata-rata Indeks Learner Perbankan Konvensional } \\ \mathrm{X}_{2} & \text { : rata-rata Indeks Learner Perbankan Syariah } \\ \mathrm{S}^{2}{ }_{1} & \text { : varian Perbankan Konvensional } \\ \mathrm{S}^{2}{ }_{2} & \text { : varian Perbankan Syariah } \\ \mathrm{n}_{1} & \text { : banyak subyek Perbankan Konvensional } \\ \mathrm{n}_{2} & \text { : banyak subyek Perbankan Syariah }\end{array}$

\section{PEMBAHASAN}

\section{Perbandingan Kekuatan Pasar Bank Syariah Dan Konvensional}

Deskripsi variabel dalam penelitian ini adalah deskripsi nilai minimum, maksimum, dan rata-rata dari komponen-komponen yang mengukur kekuatan pasar (market power) antara lain sebagai berikut:

\section{Total Revenue}

Total Revenue (TR) merupakan proksi dari total pendapatan yang diperoleh oleh perbankan konvensional dan perbankan syariah dalam suatu periode. Deskripsi total revenue perbankan konvensional dan perbankan syariah di Indonesia selama periode 2011-2015 adalah sebagai berikut: 
Penduduk Muslim sebagai Potensi Pasar Perbankan Syariah ｜ 141

Tabel 3. Total Revenue Perbankan Syariah dan

Perbankan Konvensional Periode 2011-2015

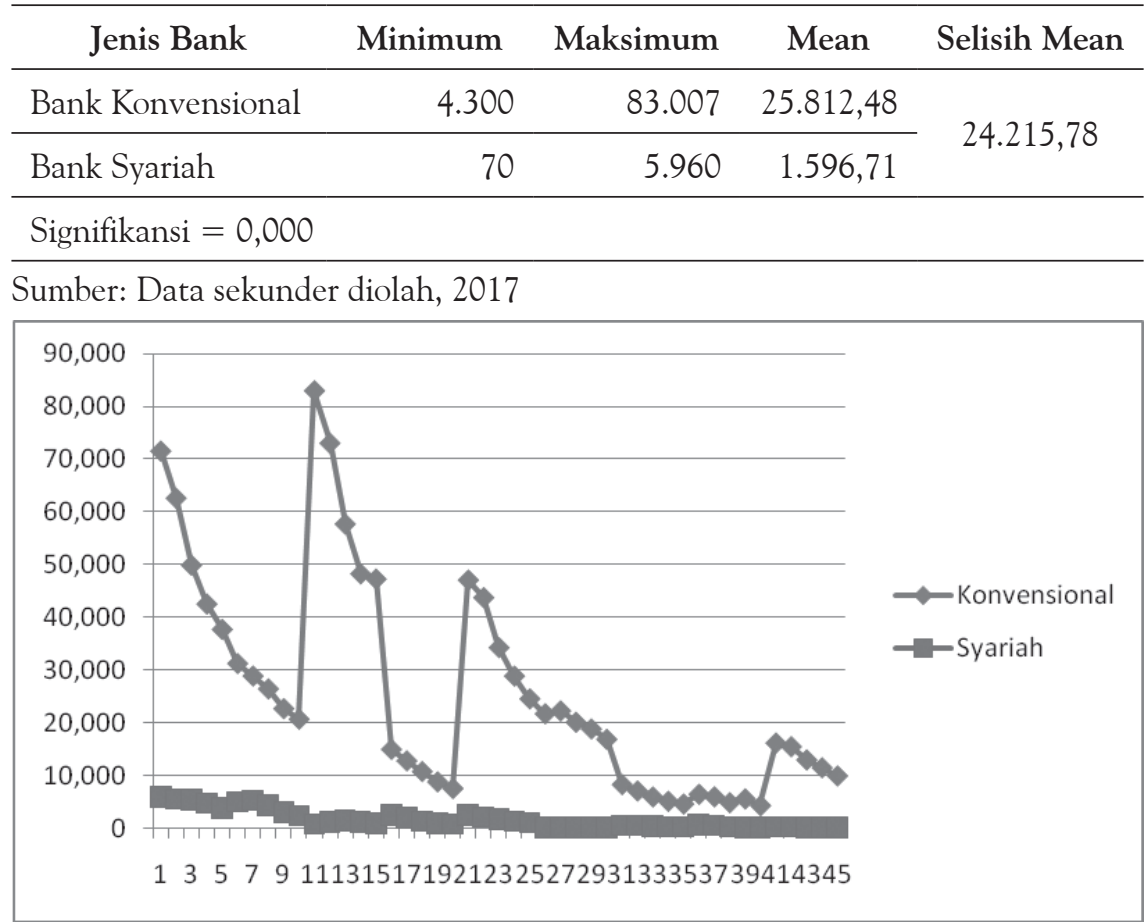

Grafik 1. Total Revenue Perbankan Syariah dan

Perbankan Konvensional Periode 2011-2015

Berdasarkan tabel di atas dapat dijelaskan bahwa selama periode 2011-2015, nilai minimum total revenue perbankan konvensional Rp4,3 triliun dan perbankan syariah Rp70 Miliar. Nilai maksimum total revenue perbankan konvensional Rp83 triliun dan perbankan syariah $\mathrm{Rp} 5,9$ triliun. Rata-rata total revenue perbankan konvensional Rp25,821 triliun lebih besar dibandingkan perbankan syariah Rp1,596 triliun. Sehingga dapat disimpulkan terdapat perbedaan total revenue perbankan konvensional dengan perbankan syariah secara signifikan dengan selisih perbedaan sebesar Rp24,215 triliun.

\section{Total Aset}

Total Aset (TA) merupakan total aset yang dimiliki oleh perbankan konvensional dan perbankan syariah dalam suatu periode. Deskripsi total aset perbankan konvensional dan perbankan syariah di Indonesia selama periode 2011-2015 adalah sebagai berikut: 
Tabel 4. Total Aset Perbankan Syariah dan

Perbankan Konvensional Periode 2011-2015

\begin{tabular}{lrrrr}
\hline \multicolumn{1}{c}{ Jenis Bank } & Minimum & Maksimum & \multicolumn{1}{c}{ Mean } & Selisih Mean \\
\hline Bank Konvensional & 7.183 & 10.063 & $318.037,48$ & \\
\cline { 1 - 4 } Bank Syariah & 1.016 & 70.369 & $18.211,02$ & \\
\cline { 1 - 4 } Signifikansi $=0,000$ & & & & \\
\hline
\end{tabular}

Sumber: Data sekunder diolah, 2017

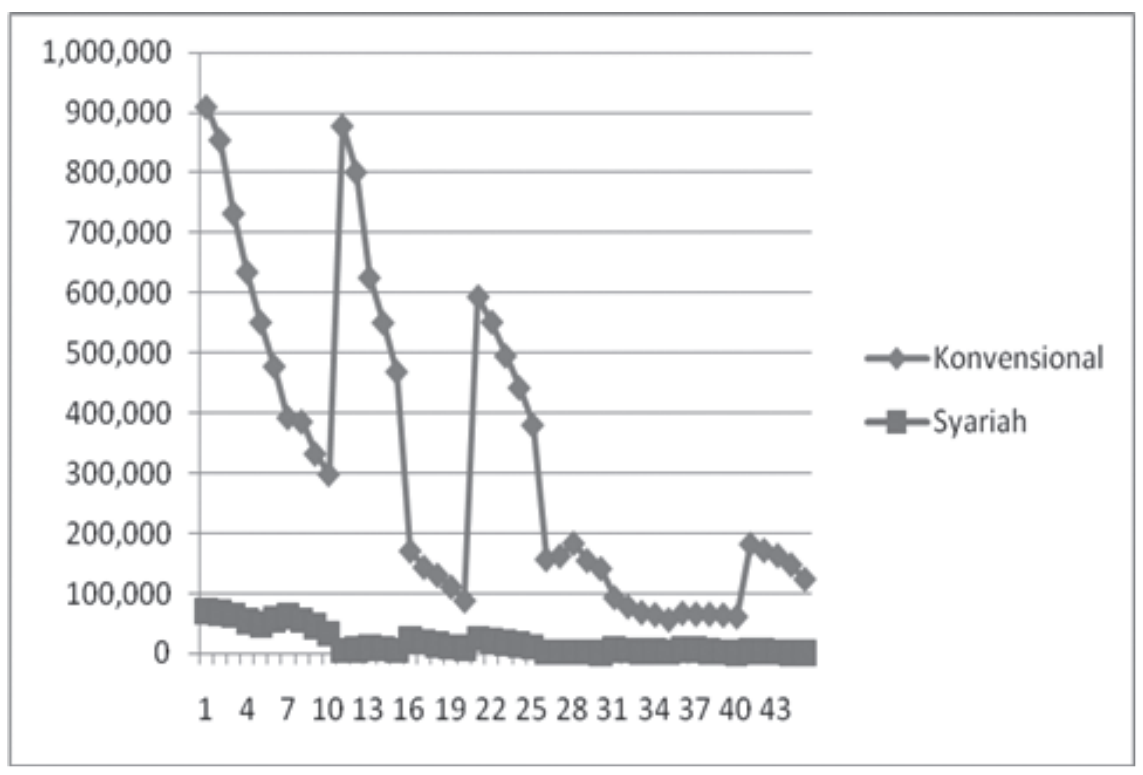

Grafik 2. Total Aset Perbankan Syariah dan Perbankan Konvensional Periode 2011-2015

Berdasarkan tabel di atas dapat dijelaskan bahwa selama periode 2011-2015, nilai minimum total aset perbankan konvensional Rp57,183 triliun dan perbankan syariah Rp1,106 triliun. Nilai maksimum total aset perbankan konvensional Rp910,063 triliun dan perbankan syariah Rp70,369 triliun. Rata-rata total aset perbankan konvensional Rp 318,037 triliun lebih besar dibandingkan perbankan syariah Rp18,211 triliun. Sehingga dapat disimpulkan terdapat perbedaan total aset perbankan konvensional dengan perbankan syariah secara signifikan dengan selisih perbedaan sebesar Rp299,826 triliun. 


\section{Biaya Tenaga Kerja}

Biaya tenaga kerja merupakan beban yang dikeluarkan untuk kepentingan gaji dan tunjangan karyawan perbankan konvensional dan perbankan syariah dalam suatu periode. Deskripsi biaya tenaga kerja perbankan konvensional dan perbankan syariah di Indonesia selama periode 2011-2015 adalah sebagai berikut:

Tabel 5. Biaya Tenaga Kerja Perbankan Syariah dan

Perbankan Konvensional Periode 2011-2015

\begin{tabular}{lrrrr}
\multicolumn{1}{c}{ Jenis Bank } & Minimum & Maksimum & \multicolumn{1}{c}{ Mean } & Selisih Mean \\
\cline { 1 - 4 } Bank Konvensional & 637 & 16.599 & $5.357,73$ & \multirow{2}{*}{$4.999,58$} \\
\cline { 1 - 3 } Bank Syariah & 14 & 1.435 & 358,15 & \\
\cline { 1 - 3 } Signifikansi $=0,000$ & & & & \\
\cline { 1 - 3 }
\end{tabular}

Sumber: Data sekunder diolah, 2017

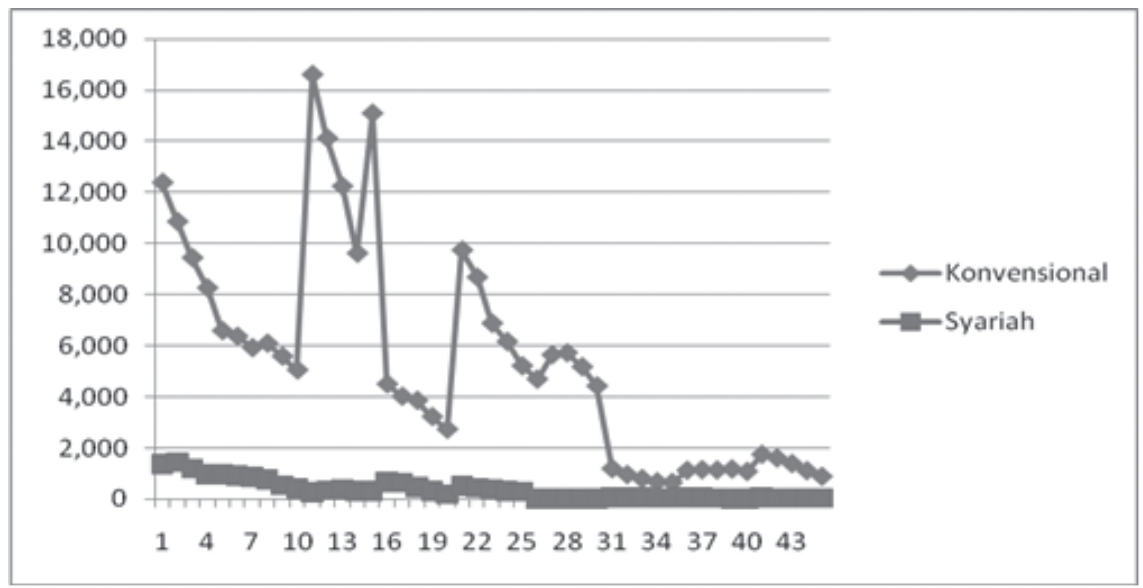

Grafik 3. Biaya Tenaga Kerja Perbankan Syariah dan Perbankan Konvensional Periode 2011-2015

Berdasarkan tabel di atas dapat dijelaskan bahwa selama periode 2011-2015, nilai minimum biaya tenaga kerja perbankan konvensional Rp637 Miliar dan perbankan syariah Rp14 Miliar. Nilai maksimum biaya tenaga kerja perbankan konvensional Rp16,559 triliun dan perbankan syariah Rp1,435 triliun. Rata-rata biaya tenaga kerja perbankan konvensional Rp5,357 triliun lebih besar dibandingkan perbankan syariah Rp358 Milyar. Sehingga dapat disimpulkan terdapat perbedaan biaya tenaga kerja perbankan 


\section{4 | Ely Masykuroh}

konvensional dengan perbankan syariah secara signifikan dengan selisih perbedaan sebesar Rp4,999 triliun.

\section{Biaya Bunga dan Biaya Bagi Hasil}

Biaya bunga merupakan beban bunga yang dikeluarkan untuk kepentingan pihak ketiga perbankan konvensional dalam suatu periode. Sedangkan biaya bagi hasil merupakan hak pihak ketiga dari pendapatan operasional perbankan syariah dalam suatu periode. Deskripsi biaya bunga perbankan konvensional dan biaya bagi hasil perbankan syariah di Indonesia selama periode 2011-2015 adalah sebagai berikut:

Tabel 6. Biaya Bunga Perbankan Konvensional dan

Biaya Bagi hasil Perbankan Syariah Periode 2011-2015

\begin{tabular}{lrrrr}
\hline \multicolumn{1}{c}{ Jenis Bank } & \multicolumn{1}{c}{ Minimum } & Maksimum & \multicolumn{1}{c}{ Mean } & Selisih Mean \\
\cline { 1 - 4 } Bank Konvensional & 2.169 & 26.207 & $8.975,67$ & \multirow{2}{*}{$8.263,38$} \\
\cline { 1 - 3 } Bank Syariah & 11 & 3.352 & 712,29 & \\
\hline
\end{tabular}

Signifikansi $=0,000$

Sumber: Data sekunder diolah, 2017

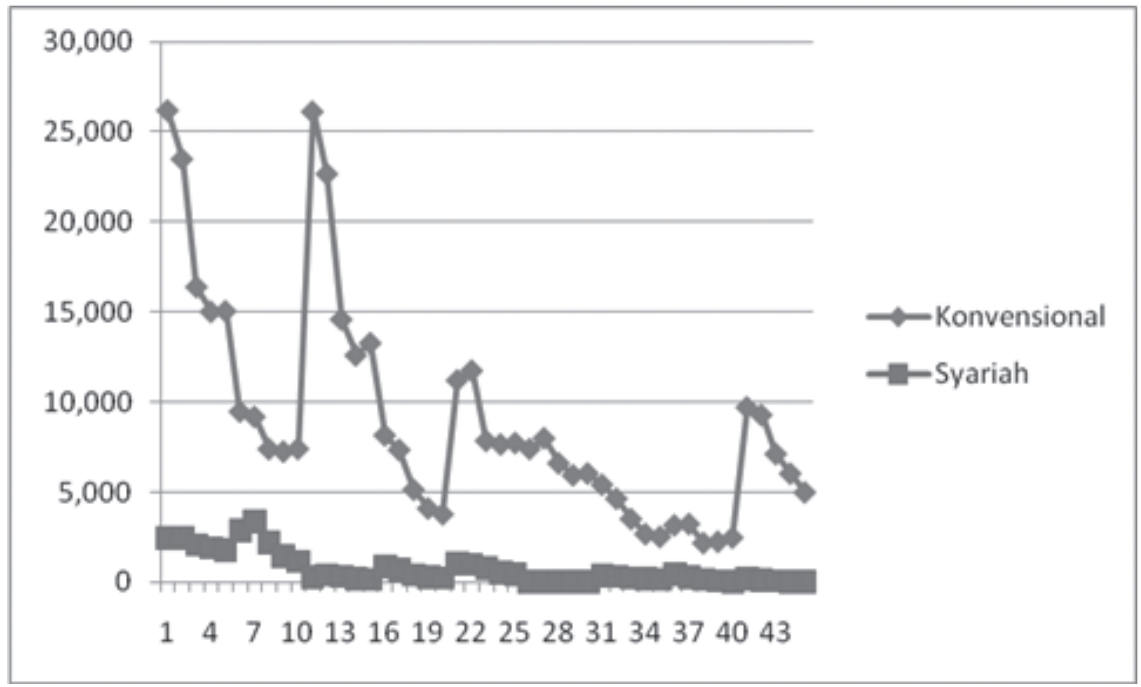

Grafik 4. Biaya Bagi Hasil Perbankan Syariah dan

Biaya Bunga Perbankan Konvensional Periode 2011- 2015

Berdasarkan tabel di atas dapat dijelaskan bahwa selama periode 2011-2015, nilai minimum biaya bunga perbankan konvensional Rp 2,169 triliun dan biaya bagi hasil perbankan syariah Rp 11 Milyar. 
Nilai maksimum biaya bunga perbankan konvensional Rp 26,207 triliun dan biaya bagi hasil perbankan syariah $\mathrm{Rp} 3,352$ triliun. Rata-rata biaya bunga perbankan konvensional Rp 8,975 triliun lebih besar dibandingkan biaya bagi hasil perbankan syariah $\mathrm{Rp} 712$ Milyar. Sehingga dapat disimpulkan terdapat perbedaan biaya bunga perbankan konvensional dengan biaya bagi hasil perbankan syariah secara signifikan dengan selisih perbedaan sebesar $\mathrm{Rp}$ 8,263 triliun.

\section{Total Cost}

Total Cost (TC) merupakan nilai kumulatif dari biaya tenaga kerja, biaya bunga perbankan konvensional dan biaya bagi hasil perbankan syariah dalam suatu periode. Deskripsi total cost perbankan konvensional dan perbankan syariah di Indonesia selama periode 2011-2015 adalah sebagai berikut:

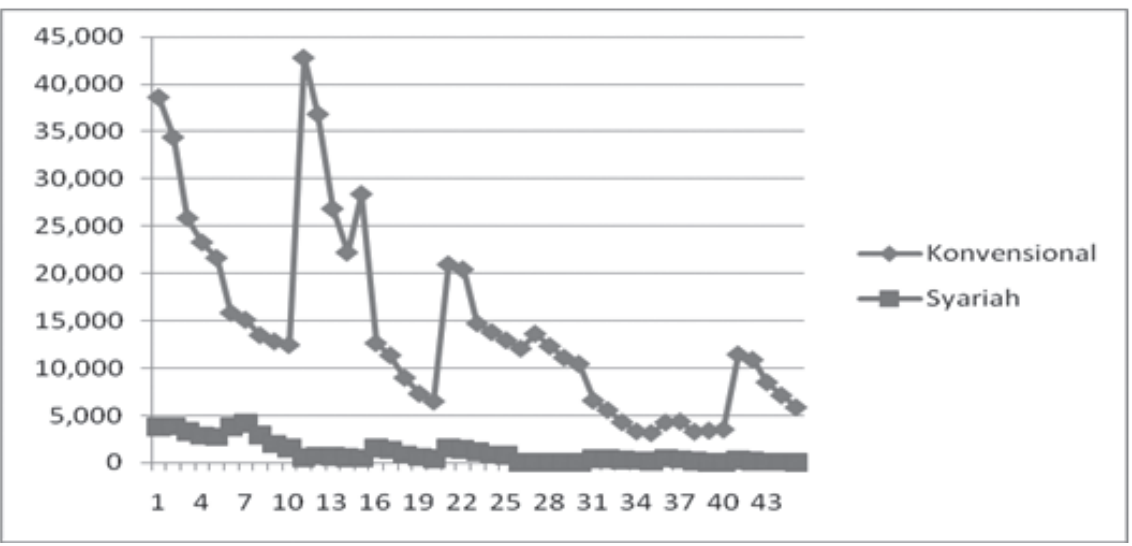

Grafik 5. Total Cost Perbankan Syariah dan

Perbankan Konvensional Periode 2011-2015

Berdasarkan tabel di atas dapat dijelaskan bahwa selama periode 2011-2015, nilai minimum total cost perbankan konvensional $\mathrm{Rp}$ 3,153 triliun dan perbankan syariah Rp 29 Milyar. Nilai maksimum total cost perbankan konvensional Rp 42,740 triliun dan perbankan syariah $\mathrm{Rp}$ 4,210 triliun. Rata-rata total cost perbankan konvensional Rp 14,333 triliun lebih besar dibandingkan perbankan syariah $\mathrm{Rp}$ 1,070 triliun. Sehingga dapat disimpulkan terdapat perbedaan total cost perbankan konvensional dengan perbankan syariah secara signifikan dengan selisih perbedaan sebesar Rp 13,262 triliun. 


\section{Harga (Price)}

Harga (Price) merupakan rasio dari total pendapatan dengan total aset perbankan konvensional dan perbankan syariah dalam suatu periode. Deskripsi total harga (price) perbankan konvensional dan perbankan syariah di Indonesia selama periode 2011-2015 adalah sebagai berikut:

Tabel 7. Harga (Price) Perbankan Syariah dan

Perbankan Konvensional Periode 2011-2015

\begin{tabular}{lrrrr}
\hline \multicolumn{1}{c}{ Jenis Bank } & \multicolumn{1}{c}{ Minimum } & Maksimum & \multicolumn{1}{c}{ Mean } & Selisih Mean \\
\hline Bank Konvensional & 0,06 & 0.14 & 0,084 & \multirow{2}{*}{0,005} \\
\cline { 1 - 4 } Bank Syariah & 0,06 & 0.17 & 0,090 & \\
\hline
\end{tabular}

Signifikansi $=0,245$

Sumber: Data sekunder diolah, 2017

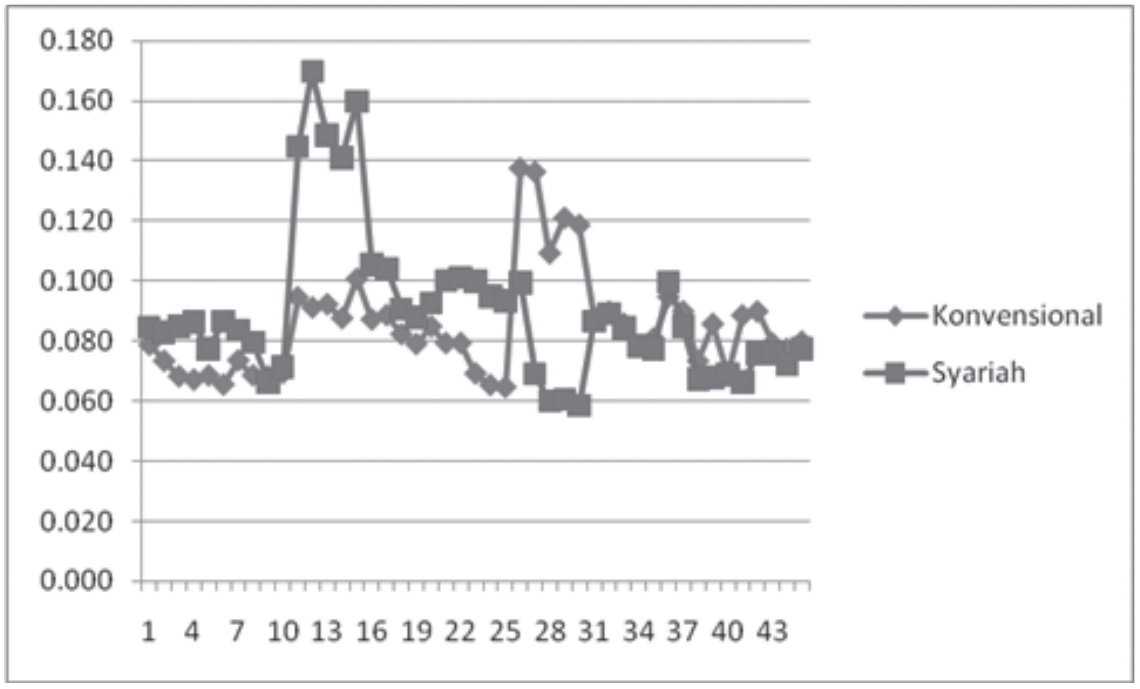

Grafik 6. Harga (Price) Perbankan Syariah dan

Perbankan Konvensional Periode 2011-2015

Berdasarkan tabel di atas dapat dijelaskan bahwa selama periode 2011-2015, nilai minimum harga (price) perbankan konvensional 0,06 dan perbankan syariah 0,06 . Nilai maksimum harga (price) perbankan konvensional 0,14 dan perbankan syariah 0,17. Ratarata harga (price) perbankan konvensional 0,084 relatif lebih murah dibandingkan perbankan syariah 0,090. Sehingga dapat disimpulkan tidak terdapat perbedaan harga (price) perbankan konvensional 
dengan perbankan syariah secara signifikan karena selisih perbedaan yang relatif kecil 0,005.

\section{Marginal Cost}

Marginal Cost (MC) merupakan rasio dari total cost dibandingkan dengan total aset perbankan konvensional dan perbankan syariah dalam suatu periode. Deskripsi marginal cost (MC) perbankan konvensional dan perbankan syariah di Indonesia selama periode 2011-2015 adalah sebagai berikut:

Tabel 8. Marginal Cost (MC) Perbankan Syariah dan

Perbankan Konvensional Periode 2011-2015

\begin{tabular}{lrrrr}
\hline \multicolumn{1}{c}{ Jenis Bank } & Minimum & Maksimum & \multicolumn{1}{c}{ Mean } & Selisih Mean \\
\cline { 1 - 4 } Bank Konvensional & 0,03 & 0.08 & 0,052 & \multirow{2}{*}{0,004} \\
\cline { 1 - 2 } Bank Syariah & 0,02 & 0.11 & 0,057 & \\
\cline { 1 - 3 } Signifikansi $=0,158$ & & & & \\
\hline
\end{tabular}

Sumber: Data sekunder diolah, 2017

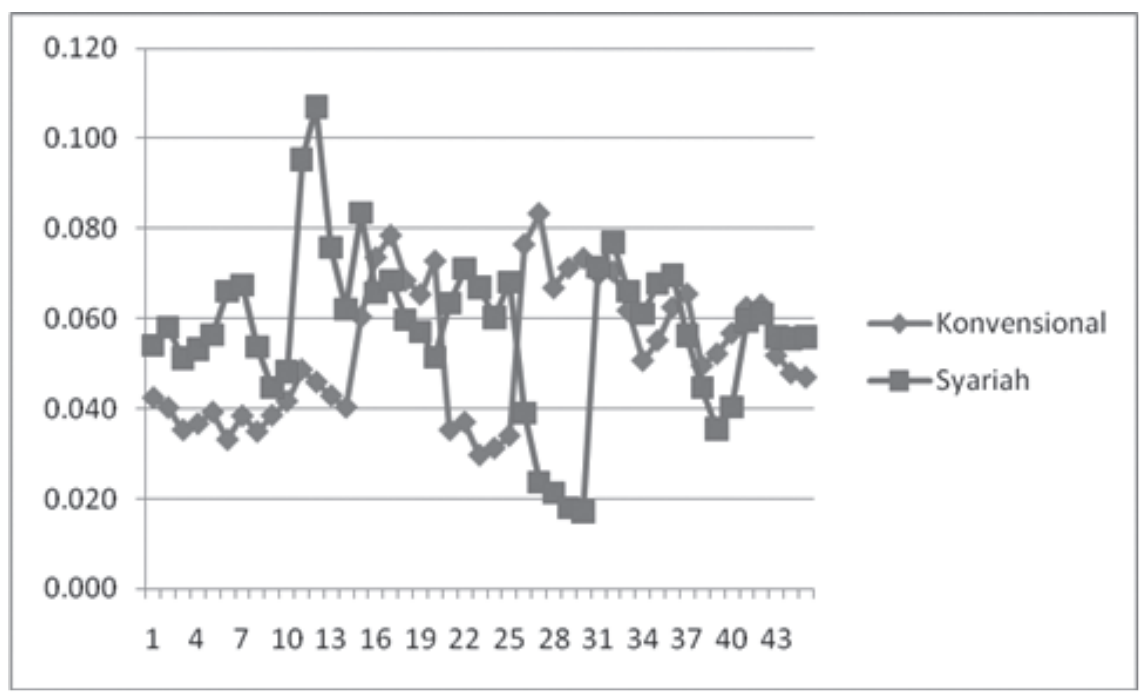

Grafik 7. Marginal Cost (MC) Perbankan Syariah dan Perbankan Konvensional Periode 2011-2015

Berdasarkan tabel di atas dapat dijelaskan bahwa selama periode 2011-2015, nilai minimum marginal cost (MC) perbankan konvensional 0,03 dan perbankan syariah 0,02. Nilai maksimum marginal cost $(\mathrm{MC})$ perbankan konvensional 0,08 dan perbankan 
syariah 0,11. Rata-rata marginal cost (MC) konvensional 0,052 relatif lebih kecil dibandingkan perbankan syariah 0,057. Sehingga dapat disimpulkan tidak terdapat perbedaan marginal cost (MC) perbankan konvensional dengan perbankan syariah secara signifikan karena selisih perbedaan yang relatif kecil 0,004.

\section{Indeks Lerner}

Indeks Lerner (IL) merupakan rasio kekuatan pasar yang diukur dengan selisih antara harga dengan marginal cost dibagi dengan harga jasa perbankan konvensional dan perbankan syariah dalam suatu periode. Deskripsi Indeks Lerner (IL) perbankan konvensional dan perbankan syariah di Indonesia selama periode 2011-2015 adalah sebagai berikut:

Tabel 9. Indeks Lerner (IL) Perbankan Syariah dan Perbankan Konvensional Periode 2011-2015

\begin{tabular}{lrrrr}
\hline \multicolumn{1}{c}{ Jenis Bank } & Minimum & Maksimum & \multicolumn{1}{c}{ Mean } & Selisih Mean \\
\cline { 1 - 4 } Bank Konvensional & 0,11 & 0.57 & 0,378 & \multirow{2}{*}{0,025} \\
\cline { 1 - 3 } Bank Syariah & 0,10 & 0.71 & 0,355 & \\
\cline { 1 - 3 } Signifikansi $=0,158$ & & & & \\
\hline
\end{tabular}

Sumber: Data sekunder diolah, 2017

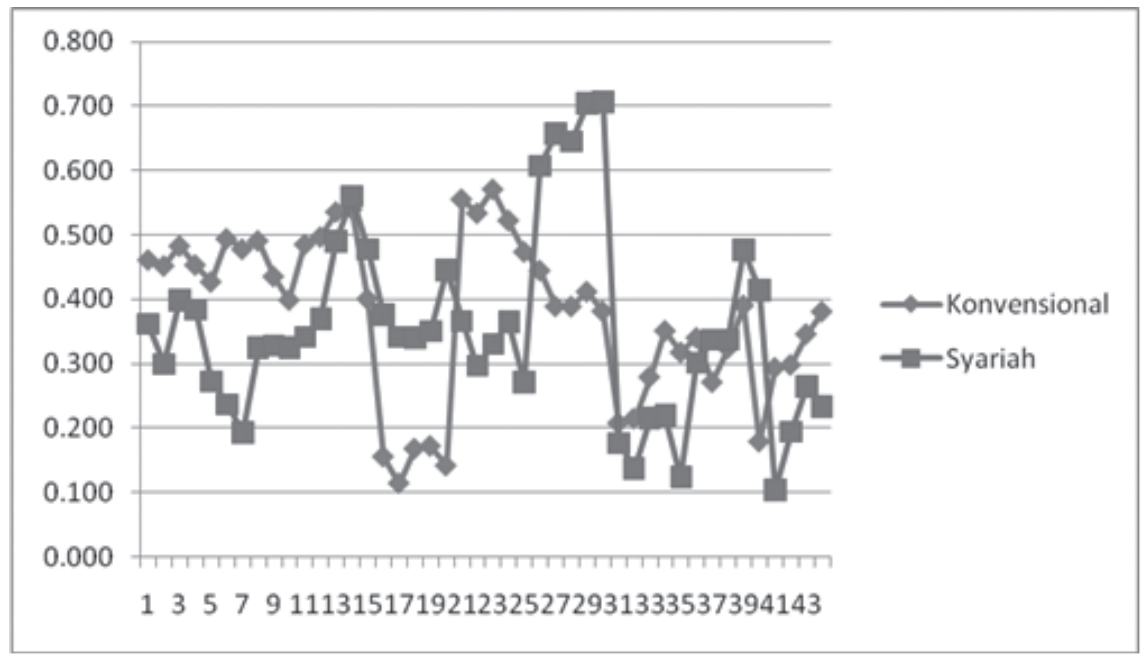

Grafik 8. Indeks Lerner (IL) Perbankan Syariah dan Perbankan Konvensional Periode 2011-2015 
Berdasarkan tabel di atas dapat dijelaskan bahwa selama periode 2011-2015, nilai minimum Indeks Lerner (IL) perbankan konvensional 0,11 dan perbankan syariah 0,10. Nilai maksimum Indeks Lerner (IL) perbankan konvensional 0,57 dan perbankan syariah 0,71. Rata-rata Indeks Lerner (IL) konvensional 0,378 relatif lebih besar dibandingkan perbankan syariah 0,355. Sehingga dapat disimpulkan tidak terdapat perbedaan Indeks Lerner (IL) perbankan konvensional dengan perbankan syariah secara signifikan karena selisih perbedaan yang relatif kecil 0,025. Komponen-komponen yang mengukur kekuatan pasar (market power) perbankan syariah dan perbankan konvensional adalah total revenue, total aset, biaya tenaga kerja, biaya bunga dan bagi hasil, total cost, harga, marginal cost, dan indeks Lerner. Untuk mengetahui perbedaan kekuatan pasar antara perbankan konvesional dengan perbankan syariah di Indonesia menggunakan analisis Uji Beda independen sample T-test yang menguji dua rata-rata dari dua kelompok data yang independent dengan bantuan software SPSS.16.

\section{Perbedaan Rata-rata Kekuatan Pasar}

Untuk mengetahui perbedaan rata-rata (mean) kekuatan pasar antara perbankan konvesional dengan perbankan syariah di Indonesia menggunakan bantuan software SPSS.16 dengan hasil sebagai berikut:

Tabel 10. Perbedaan Rata-Rata Kekuatan

Pasar Perbankan Konvensional dan Perbankan Syariah

Group Statistics

\begin{tabular}{llcrrr}
\hline \multicolumn{1}{c}{ Jenis Bank } & N & Mean & Std. Deviation & Std. Error Mean \\
\hline \multirow{2}{*}{ Bank } & Bank Konvensional & 45 & .3788 & .12439 & .01854 \\
& Bank Syariah & 45 & .3528 & .14543 & .02168 \\
\hline
\end{tabular}

Berdasarkan tabel di atas dapat diketahui bahwa tingkat kekuatan pasar perbankan konvensional berdasarkan rata-rata (mean) Indeks Lerner adalah sebesar 0,378. Sedangkan tingkat kekuatan pasar perbankan syariah berdasarkan rata-rata (mean) Indeks Lerner adalah sebesar 0,352. Dengan demikian dapat disimpulkan bahwa tingkat kekuatan pasar perbankan konvensional lebih besar dibandingkan dengan perbankan syariah di Indonesia. 


\section{Uji Hipotesis}

Untuk menguji hipotesis kekuatan pasar (market power) perbankan syariah lebih besar dibandingkan kekuatan pasar perbankan konvensional di Indonesia menggunakan bantuan software SPSS.16 dengan hasil sebagai berikut:

Tabel 11. Independent Samples Test

\begin{tabular}{|c|c|c|c|c|c|c|c|c|c|c|}
\hline & \multicolumn{2}{|c|}{$\begin{array}{l}\text { Levene's } \\
\text { Test for } \\
\text { Equality of } \\
\text { Variances }\end{array}$} & \multicolumn{7}{|c|}{ t-test for Equality of Means } \\
\hline & & \multirow[t]{2}{*}{$\mathrm{F}$} & \multirow[t]{2}{*}{ Sig. } & \multirow[t]{2}{*}{$\mathrm{t}$} & \multirow[t]{2}{*}{ Df } & \multirow[t]{2}{*}{$\begin{array}{c}\text { Sig. } \\
(2 \text {-tailed) }\end{array}$} & \multirow[t]{2}{*}{$\begin{array}{c}\text { Mean } \\
\text { Difference }\end{array}$} & \multirow[t]{2}{*}{$\begin{array}{l}\text { Std. Error } \\
\text { Difference }\end{array}$} & \multicolumn{2}{|c|}{$\begin{array}{c}95 \% \text { Confidence } \\
\text { Interval of the } \\
\text { Difference }\end{array}$} \\
\hline & & & & & & & & & Lower & Upper \\
\hline Bank & $\begin{array}{l}\text { Equal variances } \\
\text { assumed } \\
\text { Equal variances } \\
\text { not assumed }\end{array}$ & .093 & .761 & $\begin{array}{l}.910 \\
.910\end{array}$ & $\begin{array}{r}88 \\
85.934\end{array}$ & $\begin{array}{l}.365 \\
.365\end{array}$ & $\begin{array}{l}.02596 \\
.02596\end{array}$ & $\begin{array}{l}.02853 \\
.02853\end{array}$ & $\begin{array}{l}-.03074 \\
-.03076\end{array}$ & $\begin{array}{l}.08265 \\
.08267\end{array}$ \\
\hline
\end{tabular}

H: Kekuatan pasar (market power) perbankan syariah lebih besar dibandingkan dengan kekuatan perbankan konvensional di Indonesia

Berdasarkan tabel di atas dapat diketahui bahwa nilai t-hitung sebesar adalah 0,910 dengan nilai signifikansi 0,365. Pengambilan keputusan didasarkan pada nilai probabilitas dengan kriteria sebagai berikut:

a) Jika probabilitas $>$ 0,05 maka Ho diterima, artinya kekuatan pasar (market power) perbankan syariah lebih kecil dibandingkan kekuatan pasar perbankan konvensional di Indonesia

b) Jika probabilitas < 0,05 maka Ho ditolak, artinya kekuatan pasar (market power) perbankan syariah lebih besar dibandingkan kekuatan pasar perbankan konvensional di Indonesia.

Berdasarkan tabel independent sampel test di atas, besarnya nilai signifikansi 0,365 jauh lebih besar dari 0,05. Berarti Ho diterima. Sehingga dapat disimpulkan bahwa kekuatan pasar (market power) perbankan syariah lebih kecil dibandingkan kekuatan pasar perbankan konvensional di Indonesia dengan selisih perbedaan mean (rata-rata) kekuatan pasar (market power) perbankan konvensional lebih besar 0,025 dibandingkan perbankan syariah.

Hasil penelitian ini menunjukkan bahwa tingkat kekuatan pasar perbankan syariah di Indonesia sebesar 0,352. Sedangkan tingkat kekuatan pasar perbankan konvensional di Indonesia sebesar 0,378. Sehingga kekuatan pasar perbankan syariah lebih kecil dibandingkan 
kekuatan pasar perbankan konvensional di Indonesia dengan selisih perbedaan kekuatan pasar perbankan konvensional lebih besar 0,025 dibandingkan perbankan syariah. Hal ini terjadi karena beberapa alasan diantaranya, adalah:

Pertama, pemahaman dan kesadaran masyarakat yang masih rendah tentang bank syariah. ${ }^{19} \mathrm{Hal}$ ini ditunjukkan dengan indeks literasi keuangan syariah sektoral perbankan syariah hanya sebesar 6,63\% jika dibandingkan dengan indeks literasi keuangan nasional sektoral perbankan sebesar 28,94\% pada tahun 2016. Sedangkan indeks inklusi keuangan syariah sektoral perbankan syariah hanya sebesar 9,61\% jika dibandingkan dengan indeks inklusi keuangan nasional sektoral perbankan sebesar $63,63 \%$ pada tahun $2016 .{ }^{20}$

Kedua, berdasarkan observasi data total aset perbankan Indonesia per Juli 2017 menunjukkan sebesar Rp6.784.541 triliun, perbankan syariah hanya menguasai sebesar Rp271.065 triliun (3,99\%), sedangkan perbankan konvensional mendominasi sebesar Rp6.513.476 (96\%). ${ }^{21}$ Besar atau kecilnya penguasaan aset oleh suatu bank menunjukkan ukuran bank dan kekuatan bank dalam penguasaan pasar.

Ketiga, keberadaan perbankan konvensional di Indonesia relatif lebih lama dibandingkan dengan perbankan syariah. Hal ini ditunjukkan dengan masa awal berdirinya bank syariah pertama kali pada tahun 1992, sedangkan perbankan konvensional lebih dahulu bahkan sebelum Indonesia merdeka. Hal ini berdampak pada tingginya loyalitas masyarakat Indonesia terhadap perbankan konvensional dan enggan untuk bertransaksi dengan perbankan syariah yang relatif baru.

\section{PENUTUP}

Berdasarkan analisis hasil penelitian dan dapat diambil kesimpulan yaitu tingkat kekuatan pasar perbankan syariah di Indonesia sebesar

\footnotetext{
${ }^{19}$ https://finance.detik.com/moneter/3076959/7-hambatan-yang-buat-bank-syariahlambat-berkembang-di-ri, diakses pada tanggal 23 Oktober 2017, pkl. 14.54.

${ }^{20}$ Otoritas Jasa Keuangan, Survey Nasional Literasi dan Inklusi Keuangan 2016, http://www.ojk.go.id/id/berita-dan-kegiatan/siaran-pers/Documents/Pages/Siaran-PersOJK-Indeks-Literasi-dan-Inklusi-Keuangan-Meningkat/17.01.23\%20Tayangan\%20\%20 Presscon\%20\%20nett.compressed.pdf, diakses pada tanggal 23 Oktober 2017, pkl 15.23.

${ }^{21}$ Otoritas Jasa Keuangan, Statistik Perbankan Indonesia, Juli, Volume 15, No. 08, hal. 47.
} 
0,352, sedangkan tingkat kekuatan pasar perbankan konvensional di Indonesia sebesar 0,378. Kekuatan pasar perbankan syariah lebih kecil dibandingkan kekuatan pasar perbankan konvensional di Indonesia dengan selisih perbedaan kekuatan pasar perbankan konvensional lebih besar 0,025 dibandingkan perbankan syariah. Beberapa saran yang dapat diberikan yaitu bagi Perbankan Syariah hendaknya selalu berupaya meningkatkan kekuatan pasarnya dengan cara mengembangkan aset dan meningkatkan pendapatan serta mengurangi total cost. Sedangkan untuk peneliti selanjutnya hendaknya untuk mengadakan penelitian lebih lanjut dengan jumlah sampel yang lebih besar dan jumlah observasi yang lebih banyak serta menggunakan proksi lain dalam mengukur kekuatan pasar perbankan.

\section{DAFTAR RUJUKAN}

Abbasi, Taimoor Hassan, Ambalen Kauser, Huma Ashiq, Hefza Inam, Humara Nazar \& Rabia Amjad. 2012. Corporate social responsibility disclosure ( a comparation between Islamicand conventional firm institution in Bahawalpur region). Research Journal of Accounting and Finance. Vol 3 (3), 51-63

Abdul Ghafur Anshori, Perbankan Syariah di Indonesia, Edisi Revisi (Yogyakarta: Gajah Mada University Press, 2009), 9

.Perbankan Syariah di Indonesia, 7

Antonio, M. Syarfi'i. 2001. Perbankan Syariah dari teori ke Praktek, (Jakarta: Gema Insani Press)

Ascarya dan Yumanita, 2006, "The Lack of Profit and Lost Sharing Financing in Indonesia Islamic Banks: Problems and Alternative Solution, paper INCEIF Islamic Banking and Finance Education Colloqullium, KL Convention Center, Kuala Lumpur Malaysia, April 3-5 . 2006 
Buang, Ahmad Hidayat. 2012. "The Role of Sharia Economy in The

Contemporary World: Challenges and Possibility for Reshaping the Global Economic Order" paper presented at International Seminar on Sharia Economics STAIN Ponorogo, 4 of July 2012

Bungin, Burhan. 2001. Metodologi Penelitian Sosial Format format Kuantittatif dan Kualitatif. Surabaya: Airlangga University Press, pp 123

Burgent, I and FuB, 2004, "Islamic banking credit products in Germany and in the UK", working paper series no. 12, Dept. of Finance, European Business school, International University Scholar Reichartshausen

Cetorelli N and M Gambera. 2001. Banking market structure, financial dependence and growth; International Evidence from Industry data. Journal of Finance 56:617- 648 .

El-Gamal, M. 2007. Incoherence of Contract Based Islamic Financial Jurisprudence in The Age of Financial Engineering, Rice Univercity, mimeo

Hanif, Muhammad, Mahris Tariq Arsshiya Taher Wajesh ul Momeneen. 2012. Comparative performance study of conventional and Islamic banking is Pakistan. International Research Journal of Finance and Economics, Issues 83 (2012) hal.62-73

Hameed, Shahul, Ade wirma, Bakhtiar Ar Rrazi, M Nazli bin Mohamed Nor. Sigit Pramono, 2004. "Alternative Disclosure dan Performance for Islamic Bank's. Proceeding of The Second Conference on Administrative Science: Meeting The Challenges of The Globalization Age. Dahran, Saud Arabia.

Hasan, Abdul \& Sofyan Safri Harahap, 2010, Exploring corporate social responsibility disclosure: the case of Islamic banks, International Journal of Islamic Midlle Eastern Finance and Management, Vol 3 (3), 203-227

J Jayaratne and P Strahan. 1996. The finance-growth nexus: Evidence from bank branch deregulation. Quarterly Journal of Economics. 111: $639-670$ 
Kamali, Muhammad Hasyim, 1989, "Sourse, Nature, and Objectives of Shari'ah” The Islamic Quarterly, 215-235, Lihat juga Adnan: 2007; Choudhury:1991; Dusuki:2006.

Kauser, Rehana \& Irum Saba. 2012. Gauging the financial performance of banking sector using CAMEL model: comparition of conventional bank, mixed and pure Islamic bank in Pakistan. International Research Journal of Finance and Economics. Issues 82 (2012), hal.67-89

Kazarian, E. G. (1993), "Islamic Versus Traditional Banking: Financial Innovation in Egypt”, Boulder : West view Press

Kuran, T. 1995. Islam and Mammon. Princeton Univercity Press: Princeton

Levina R. 2005. Finace and growth dalam Aghion and Durlauf. Handbook of Economic Growth, Elselvier: North-Holland

Muhammad, Manajemen Bank Syarah, Edisi revisi, (Yogyakarta: AMP YKPN (UPP), 2005), 15

Nor, Shifa Mohd \& Mehmet Asutay. 2012. Re-considering corporate social responsibility and sustainability identity of Islamic banking in Malaysia: an empirical analysis. Working paper preceedding in International Conference of Islamic Economics and Finance. Qotar 2012

Parrvez, Zahil \& Parvaiz Ahmed. 2004, An Islamic perspective on the lack of social responsibility in business organizations, Working Papers

Rosly, Saiful a \& Mohd A Abu Bakar, 2003, Performance of Islamic and mainstream banks in Malaysia, International Journal of Social Economics, Vol 30 (11/12), 1249-1265

Samad, Abdus and Hasan, M. Kabir, 2000. "The Performance of Malaysian Islamic Bank During 1984-1997: An Exploratory Studi”, International Journal of Islamic Financial Services, Vol.1. (1), 1-14

Sekaran, U \& Roger Bougie, 2010. Research Methods for Business A Skill Building Approach. Fifth Edition, United Kingdom: John Wiley \& Sons Ltd. Pp. 276-278 
Setiawan, Aziz Budi. 2009. "Kesehatan Finansial dan Kinerja Sosial bank Umum Syariah di Indonesia”. Disarikan dari makalah pada Seminar Nasional Kerjasama Magister Bisnis Keuangan islam Universitas Paramadina, IAE MES pada 3 juli 2009 di Jakarta

Sugiono, 2011. Metode Penelitian Pendidikan Pendekatan Kuantitatif, Kualitatifdan REDD. Bandung: Alfabeta

Scharf, Traute Wohler. 1983. Arab and Islamic Banks: New Business partners for Developing Countries (Paris: Development Center of the Organization for Economic Cooperation and Development)

Taylor, J. Michael, 2003. Islamic Banking - The Feasibility of Establishing an Islamic Bank in the United States, 40 AM. BUS. L.J. 385, 416

W Petersen and Rajan R, 1995. The effect of credit market competetionon on landing relationships. Quarterly Journal of Economics. 110: 407-443

Zubairu, Umaro M. Olalekan B Sakasiyau, Chetubo K Danda.2012. Evaluation of social reporting practies of islamic Banks in Saudi Arabia. Electronic Journal of Business Ethics and Organization Studies. Vol, 17 (1), 41-51 
